Uniwersytet Przyrodniczo-

Humanistyczny w Siedlcach

Siedlce University of Natural

Sciences and Humanities

https://bazawiedzy.uph.edu.pl

\begin{tabular}{|l|l|}
\hline Publikacja / Publication & $\begin{array}{l}\text { Comenius' man in the context of internal and external freedom towards physical, } \\
\text { intellectual and emotional spheres, } \\
\text { Wyczółkowska Ewa }\end{array}$ \\
\hline $\begin{array}{l}\text { Adres publikacji w Repozytorium URL } \\
\text { / Publication address in Repository }\end{array}$ & https://bazawiedzy.uph.edu.pl/info/article/UPHa6ala4400c8841ceaaaf6d8f6d46d9f3/ \\
\hline $\begin{array}{l}\text { Data opublikowania w Repozytorium / } \\
\text { Deposited in Repository on }\end{array}$ & 22 paź 2021 \\
\hline Rodzaj licencji / Type of licence & Attribution-NoDerivs (CC BY-ND 3.0) \\
\hline & $\begin{array}{l}\text { Wyczółkowska Ewa: Comenius' man in the context of internal and external freedom } \\
\text { towards physical, intellectual and emotional spheres, Siedleckie Zeszyty } \\
\text { Komeniologiczne seria PEDAGOGIKA, no. 6, 2019, pp. 319-330 }\end{array}$ \\
\hline
\end{tabular}


Ewa Wyczółkowska

ORCID: 0000-0002-2877-7204

Uniwersytet Przyrodniczo-Humanistyczny w Siedlcach

Wydział Nauk Społecznych

\title{
COMENIUS' MAN IN THE CONTEXT OF INTERNAL AND EXTERNAL FREEDOM TOWARDS PHYSICAL, INTELLECTUAL AND EMOTIONAL SPHERES
}

\author{
KOMEŃSKIEGO CZŁOWIEK W KONTEKŚCIE WOLNOŚCI \\ WEWNĘTRZNEJ I ZEWNĘTRZNEJ - WOBEC SFERY CIELESNEJ, \\ INTELEKTUALNEJ I EMOCJONALNEJ
}

DOI: $10.5604 / 01.3001 .0013 .6259$

\begin{abstract}
Is comeniology a science? This question becomes the guiding thought of my contemplations. I conduct the analysis of John A. Comenius's concept according to the selected scientific criteria: logical order, levels of theory, explanatory power, heuristic power, degree of persuasion and degree of justification, power of prediction, language and methods. I accept the image of a man as a triad involving spirit (immortal part connected with the spiritual world), soul (rational part considering the free will given by the Creator) and body (animal part and the part of the soul capable of perceiving sensory stimuli). In my article I am searching for a proper interpretation of Comenius' concept of a free man that was based on observation and experience.

Keywords: man, person, freedom, values, love, emotions, science, assertions, object of research, research methods

Streszczenie: Czy komeniologia jest nauką? Pytanie to staje się przewodnią myślą moich rozważań. Analizę koncepcji Jana A. Komeńskiego poprowadzę według wybranych kryteriów naukowości: porządku logicznego, poziomu teoretyczności, mocy wyjaśniającej, mocy heurystycznej, stopnia przekonania i stopnia uzasadnienia, mocy przewidywania, języka i metod. Przyjmuję obraz człowieka jako triady obejmującej ducha (część nieśmiertelna powiązana ze światem duchowym), duszę (część rozumna licząca się z wolną wolą daną od Stwórcy) i ciało (część zwierzęca oraz część duszy zdolna do przyjmowania bodźców zmysłowych). W swoim artykule poszukuję właściwej interpretacji koncepcji człowieka wolnego u Komeńskiego, który bazował na obserwacji i doświadczeniu.
\end{abstract}

Słowa kluczowe: człowiek, osoba, wolność, wartości, miłość, emocje, nauka, twierdzenia, przedmiot badań, metody badań 
In ancient times nature was the subject of any study that is why people were seen through its prism. Therefore, a man was described as a microcosm, which means the inseparable unity of a human with the cosmos. Protagoras, however, initiated relativism that stated an anthropological approach. He studied the variability of individuals depending on culture and socioeconomic conditions. As well Democritus, the creator of the atomistic theory of matter, described a man as a micros cosmos. According to Protagoras, a man is the measure of all things, in other words, cognition depends on the man, his point of view and assessment. Quite a different view of a man was suggested by Socrates who created the image of a man in various ethical aspects. Socrates assumed that a man should strive for virtue; the gift in which he saw human's happiness (Furmanek, 1995: 12-14). The connection between a man and the space is also seen in Plato's idea. For the philosopher the cosmos was ordered, governed according to the principles of proportion and harmony (Wielgos, 1999: 57).

Human image concepts evolved over the years, the changes generated historical, cultural, religious and political events.

Regardless of the perception of a man as a microcosm, John Amos Comenius derived his own concept of the man from the biblical root (Borkowski, 2015: 138-139). The educator created a "system of justified concepts, assertions and hypotheses, which were the product of explorative research activity and were the most developed form of social awareness" (Okoń, 1996: 186). The subject of this scientific research became a man as a psychophysical being that is a spiritual figure. Thus, John Amos Comenius focused his contemplations on a man within the triad involving spirit (immortal part connected with the spiritual world), soul (rational part considering the free will given by the Creator) and body (animal part and the part of the soul capable of perceiving sensory stimuli). Such a division satisfied the need of scientific theory creation. In the gained pattern of a man by Comenius there emerged the believes about taking care of soul, mind and body; as well as justifications for the human body which should be a worthy "dwelling" for the beautiful soul, alongside with the mind - to manifest the wisdom that flows from the God (Comenius, 2017: 21).

It should be noted that as in the case of social sciences of today, the subject of Comenius' entries was educational activity aimed at shaping the man in all the areas of life, both for his own and social good. The Moravian created regulations based on the observations and his own experience. The concept of 
upbringing built by the educator covered physical, intellectual, moral and social areas. Undoubtedly, he referred to the subjectivity of children and youth and, thus, to their harmonious development. He affirmed the role of parents, teachers and other entities participating in the creation of favourable conditions that would release the potential of children and youth and orientate them in the choice of values. In his considerations self-improvement of the ward by choosing the right methods (e.g. games) and tools (e.g. toys) was of great importance. Obviously, he was aiming at self-improvement of an individual in the process of self-determination.

Consequently, the logical ordering of Comenius' rules leads to one of the basic moral values, namely freedom. Barbara Sitarska (after Comenius) warns against reckless exercise of freedom. She suggests (after Comenius) that the condition of learning the boundaries between freedom properly understood and misunderstood is the recognition of good and evil (Sitarska, 2014: 314-316). The author, in her attempt to define freedom, refers to Comenius' appeal: "Let everyone be allowed to decide about those things they know thoroughly; let them exercise their right of free choice, but without making mistakes; let them be allowed to rely on their own choice, but when it is obvious that the better was chosen, not the worse." In general, a man should do everything not under duress, but of his own free will. Looking from the perspective of observation and philosophical and pedagogical considerations in the field of freedom, Barbara Sitarska (after Comenius) took the position that "if such freedom flourished everywhere, everything would be full of both light and order, and instead of a flood of violence and oppression, there would come, with the wave of voluntary activities, peace and safety. " (Comenius, 1979: 49).

The above quoted Comenius' thoughts "touch" the structure of science because they have the character of statements adopted by direct sensory experience (Cackowski et al., 1987: 416). Cezary Kalita has no illusions about the scientific nature of Comenius' assertions. In his opinion, Comenius was a scholar of the time, as evidenced by his contribution into didactics. In addition, in the 17th century the concept of a scholar did not exist, there were no scientific specializations, and all the scientific theories used to arise under the auspices of philosophy. It was not until the 18th century that the image of a scholar was created (Kalita, 2007: 91-98; Kalita, 2016: 65).

Moreover, Cezary Kalita in his philosophical considerations suggests that Comenius' achievements should be considered in a broader context. This also applies to freedom. He claims that Comenius does not limit freedom to science, whereas he boldly recognizes the importance of freedom in politics 
and religion. As he writes: "for Comenius practicing science is associated with the political consequences of religious tolerance. Freedom flourishes in politics, while science fastens the flourishing. Comenius' religious issue also plays a key role, its optics concern every fragment of human activity (...). Religious freedom guarantee has to be politically sanctioned and Comenius is fully aware of this. " (Kalita, 2016: 66-67).

Comenius' intention was to distinguish between two types of freedom, namely, internal freedom and external freedom. The in-depth analysis of Comenius' legacy allows us to assume that if freedom is considered in relation to the soul and spirit that condition man's attitude to various aspects of reality, then one speaks of internal freedom. It is based on improving oneself so as not to fall into a conflict with others, and only to desire what is achievable or realizable. When the obstacles to living in harmony that appear in sociopolitical and religious reality are focused on, one refers to external freedom. In the light of these words, internal freedom guarantees external freedom. An internally free person manages his own destiny, decides about himself, and speaks constructively without fear. In addition, he himself decides about his actions in the surrounding world. Not always the subjective thinking that one is a free man is transferred into a real fact. (Dziewiecki, 2006: 212-221). Dziewiecki considers whether the warranty of external freedom is a sufficient guarantee for the existence of internal freedom. One must notice that in his opinion there is no such implication. Furthermore, there is no implication in the opposite direction. Generally speaking, the sign of equivalence between internal freedom and external freedom can be put (Dziewiecki, 2006: 212-214).

As a rule, freedom is a "certain given from birth trait of a man" (Amsterdam, 1983: 172), whereas, in fact, it is an illusion, as every individual from his birth is subjective to certain systems. Comenius recognized the fragility of human life on Earth, in Labyrinth of the World and Paradise of the Heart he refers to man's journey through the world full of dangers, labyrinths and ambushes (Szymonik, 2015: 131). "This threatening world, in fact, causes that the pilgrim character of Comenius is look for safety and a point of support, finding them in his heart, seeing Christ himself who teaches him how to act in this complex reality" (Borkowski, 2015: 140). Assuming that the man following the path of light coming from the source will reach his destination, Comenius rationally accepted the thesis defining the closeness of a man and the Creator. Therefore, in the Thinker's conviction, a man should seek happiness within himself and not in the illusion of the surrounding world. Comenius came to the original truth, he considered a man as a free user of the world 
which determines the universal good. In the light of his words freedom is the light and guidance in voluntary actions (Comenius, 1956; Comenius, 1979; Comenius, 2017).

Undoubtedly, "the purpose of science is to search proper elucidation for everything that needs explaining. By elucidation (or causal explanation) I mean a set of sentences, one of which describes the state of things that requires explicitness (explicandum), while the others, explanatory sentences, constitute the "explanation" in the narrower sense of the word (the explanans for this explicandum)" (Popper, 1992: 249). Philosopher Popper continued in his work that "any elucidation may be the subject of further explanation by theory or hypothesis with a higher degree of universality. There is no elucidation that does not need any further explanation, because no elucidation can be a self-explanatory description of the being of some sort" (Popper, 1992: 254). It is worth emphasizing that the goal of many sciences is to look for elucidations of human potential and capabilities. It would mean - I think - that Comenius did explain the potential and possibilities of a free man.

Sławomir Sztobryn grouped the described thesis about the potential and possibilities of a free man by Comenius in his writings into two categories.

The first category - empirical theses:

Man is to prevail over other living beings;

Man is "the most complex creature... he contains the inherent qualities of all other creatures";

Man is a harmonious and, hence, beautiful being;

Man can extract knowledge from empirical data and go beyond them;

The most important quality of a man is the will, not the reason; the will is the "core of nature";

Man is a dualistic being (body and soul);

Man is a being that possesses self-awareness of his knowledge;

Man - unlike the whole bios - is able to generate many consequences from accumulated experience.

The second category - transcendental theses (referring to the ability to cross borders):

Man, because of his spiritual contact with the deity, is to be God's "source of eternal joy";

Man is subjected to divine predestination and it is who Comenius considers it to be "the true focal point of a man";

Man is a triadic being (body, soul, spirit);

"Human mind derives directly from God;" 
In creating a man, God provided him with his own attributes - wisdom, strength (will) and goodness (Sztobryn, 2015: 96-97).

In the light of the conducted research Comenius generated cognitive acts called understanding in which man occupies a unique place. According to Barbara Sitarska, "A man - according to Comenius - occupies a special place in the hierarchy of being because he has the ability to activate and use the three powers he possesses: ratio, oratio, operatio." (Sitarska, 2015: 146). He was raised by God to the highest levels, even above angels, what activates aspirations in the field of self-knowledge and self-improvement, search of imperfections, pursuit of the source of their occurrence, and then burning them out. Comenius wrote about the distinction of a man in nature with the words: "Let him stand out who has the opportunity; as long as he knows exactly what it really means to stand out and by which paths truly high goals are pursued, because we are already distinguished by the very law of our creation above the multitude of all the visible creatures" (Ps. 8, 6, 7). "Redemption has elevated us even above angels (Hebrews 2:16), and through sanctification we have ascended to participation in the divine nature $(2$ Peter 1,4$)$ - how wonderful!" (Comenius, 1973: 43-44.).

The heuristic power of knowledge of a man and his pursuit of freedom in the Moravian's concept is a condition for the emergence of new knowledge (Lakatos, 1995: 110-113).

Comenius created a concept addressed to parents and concerning caring for a healthy body, spiritual and mental development of their children who are more precious than gold. The proclaimed hints and pieces of advice he supported with a saying about a healthy mind in a healthy body (Comenius, 1964: 643-646; Comenius, 2017: 44-58). This way he comes to the conclusion that the body is a tool for the spirit. The Moravian assumes that through the body the spirit can express emotions, accept and give love. A man who cares for his body, spirit and soul and respects the body, spirit and soul of other people is a free and responsible man in the full sense of the word. According to Comenius' concept, such a man lives in a paradise garden where he has all the riches at his disposal: sardine stone, stone and jasper, chrysolite and onyx, beryl, sapphire, carbuncle and emerald with gold; and the day of his birth is solemn, the sound of drums and pipes can be heard. If the wisdom given to him is misused, he is thrust into the desert (Comenius, 1956: 12-13). The author tells the man lost in the world of temptations that his exile from paradise is not the final did. He expresses his further reflections with the words: God, sending "a ray of his wisdom that substantiated heaven and earth, and all 
the things existing, mercifully surrounded his abandoned paradise, human race, so that on the dead and dry trees of our hearts, undercut with an axe, stripped of the bark with a saw and a file of his law, to instil the new branches taken from the heavenly paradise; for them to be able to strike root, he sprinkled them with his own blood and never ceases to saturate them with various gifts of his holy Spirit, like streams of living water" (Comenius, 1956: 13).

Another subject of Comenius' analysis was love, which "is an affirmation of the value of a person" (Olbrycht, 2002: 182). The reflective concept created by the Pedagogue was to make the practice more conscious. Bringing up the issue of love and a deeper understanding of this theory was to affect practice. Comenius stated that the man is an instrument in the hands of the Creator, whose gifts flow into his heart and later stream outside in the process of love (Comenius, 1956: 12). He accepted that this fact favours the shaping of the attitude open to accepting love and giving love to others. According to the Thinker, children are the example worth following; they are adults' teachers on how to live in absolute love. Comenius described his thoughts with the words: "You are given to us as teachers, and your actions - as an ideal and a model for our actions" (Comenius, 1956: 18). In his opinion mature love is displayed in the balance between diligence and tenderness. Yet another way of showing love is physical and emotional presence. He, who is hardworking but does not show affection for his loved ones, does not devote enough time to them, does not say nice words or present them with gestures, and is not capable of loving. Similarly, he who is overly sensitive, yet lazy, and neglects his duties to the family, in a broad sense, does not understand what mature love is. That one does not bring light; he only kindles the darkness (Comenius, 1956: 16). A perfect example of the harmony between tenderness and diligence is the mother. The mother hugs her child, gives her kisses, feeds him, bathes and olives him, and gets up at night when he cries. She speaks warm words and ensures his successful development (Comenius, 1956: 19; Comenius, 1964: 22-30; Comenius, 2017: 26).

The quoted Comenius' thoughts about the mature love place it in the categories of the concept containing elements of basic and applied knowledge of a man. Nowadays we derive it from many different sciences, not only from pedagogy, philosophy and psychology. In addition, Comenius could not avoid theological premises that served him as incentives for building up the theory of education of a free man. In the Great Didactic we read: "In a man, as if in one stack, all the matter of the world and all shapes and degrees of shape were collected, so that they could express the entire mastery of God's wisdom" (Comenius, 1956: 11), therefore a man is an element of nature, just like the 
microcosm in relations to the macrocosm. In further characterizing a man, Comenius emphasized that he is endowed with a mind, a will and has a tree of immortality (Comenius, 1956: 11-12). Continuing the process of creation, the Creator "shaped the body with his fingers and breathed his soul out into it" (Comenius, 1956: 31). The body is not a limiter, a closed home for the spirit and soul, on the contrary, it is a tool for self-manifesting, germinating out. The belief is born that one should care for, respect and accept his body (Comenius, 1964: 12). Decorating the body, correcting and improving it by unnatural methods are the symptoms of the lack of self-acceptance, such actions imply enslavement. Submission to contemporary trends and addictions, harming others create a threat not only to the body, but also to the personality of the human, it is also connected with a low self-esteem (Dziewiecki, 2003: 40).

In his scientific achievements, the pedagogue addressed interdisciplinary issues, using religious and humanistic issues. In the Great Didactic the author is convinced that the formation of a free man requires both "sowing with the seeds of wisdom and virtue, as well as shaping sensible thinking to search for good and radiate love." (Comenius, 1956: 56-62). It is an extremely difficult task for parents and other educators, because every person has a natural tendency to resort to his subjective world. This individual world is often based on dreams and illusions; the man starts to manipulate, lie and run away from logical thinking, give in to laziness, what ultimately leads to a crisis. The process of man's maturing and upbringing is complicated and long, it includes the years of youth in which we are unproductive for household and social activities. According to Comenius, at the beginning the brain (spiritual strength) is formed which at first is soft and sticky like wax, but hardens over time. Upbringing goes nowhere when it is not based on the principles of wisdom. Specific crowning of these thoughts is the imposition upon the parents, educational and church representatives the responsibility of taking care of heavenly plants on time (Comenius, 1956: 64-67; Comenius 1964: 6-11; Dziewiecki, 2006: 110, 138-139). In the Mother School the Educator addresses the parents with the fallowing words: "Parents, consider also when the training of the mind should be started for your children. Solomon says that his father taught him when he was very young. Even although he was the only child of his mother, she did not oppose to his teaching. Similarly, the mind and our children should be developed from the very youth" (Comenius, 1964: 14-20; Comenius, 2017: 62-63). Comenius showed that being a free man means being happy. A happy man strives for comprehensive education, morality and godliness to stay in God's garden of paradise forever (Comenius, 1956: 79; Comenius, 1996: 26-28). As a result, Comenius believed that, among 
others, love for one's neighbour, truth, truthfulness and diligence are the determinants of freedom (Comenius, 2017: 97-99).

The emotional zone became the subject of the research of Comenius' concept. The author, taking into account cognitive perspectives, namely pedagogical and philosophical ones, emphasized the need for the research on emotions. Undertaking the research on the emotional sphere allowed indicating the principles of the upbringing process of a free man. According to Comenius, a fully free man shows maturity, whereas emotions inform him about his mental, intellectual and physical health and stimulate reflection. The results of his contemplations are planned strategies and actions taken in this area that are aimed at self-healing and filling oneself with absolute love. Comenius came out of the conviction that a man filled with love does not notice when he grows gradually like a tree, that "in thirty years has grown into a very broad tree" (Comenius, 1956: 116). A free man knows the power of progress and will not allow his life to be driven by emotions, either joyful or painful. As he is aware that it is not worth wasting life on meaningless things (Comenius, 1956: 111). A joyful emotional state motivates a person to act, whereas a painful one prompts one to withdraw or look for another solution. Of course, every human being, as a creature filled with spirit and soul, has the right of choice, he can pursue eternal happiness and perfection fallowing a straight path covered with rose petals or a winding one paved with rose thorns. For people who live in love, everything "flows in the process". Likewise, the painter who creates paintings with love is known and appreciated. Similarly, a gardener who puts his heart into the process of growing breeding plants will sell them at the market in abundance (Comenius, 1956: 124). Parents should do the same: love their children more than silver, gold and other treasures; treat them equally. They should give them the same love and the same respect as for themselves (Comenius, 1964: 6-11; Comenius, 2017: 14-15). Comenius' considerations of emotions are philosophical to a large extent.

It seems that the concept created by Comenius - innovative for those times - has survived the difficult test, indicating the enduring ideas from which we still derive wisdom. I will try to emphasize the thought of Karl R. Popper here, although I am aware of the fact that Comenius did not create such a theory, yet he was aiming at it: "As long as the theory comes out victorious from meticulous and stringent tests, and until - due to the progress of science - another theory does not take its place, we can say that it "proved fortitude", or that it was "corroborated" by the previous experience" (Popper, 2002: 34). 
Complementing the thought on the criteria of the "scientific character" of the Comenius's legacy, I refer to the opinion of scholars who claim that the scientific nature of the theory is determined by two basic determinants: language and method (Heller, 2009: 12). Thus, Comenius, speaking in his works about the stimulation of the development of a free man, used syntax developed in mathematical logic (inductive method), i.e. conditional sentences (of the type "if... then...") as well as the sentences not falling into the syntax of the language of mathematical logic (of the type "...that"). Formulated by him laws of "science", cited in the above text, refer to the relationship between states of affairs and the abstract constructs of Comenius's mind as a result of the phenomena directly observable by him (Amsterdamski, 1983: 60).

Comenius showed exceptional observational sensitivity, as the observed natural phenomena found a reliable basis in the creation of theoretical knowledge free of illusions (see Cackowski et al., 1987: 433-444). The content of subjective thoughts, the source of which was observations, manifests itself in this exemplary description: "Here, unfortunately, I have to stop to scold the monkey and donkey love of some parents who allow their children for all the pranks, bring them up without punishment or rod. They let the children do whatever they like, let them jump and toss on the ground, let them scream, bite, let their show their tongue, let them display the greatest disobedience, let them interfere in the conversation of the elders, let them be fussy and behave surly. Parents can accept all of this. The child, in their opinion, will remain a nice kid who cannot be paid attention to anything, because he does not understand it yet. Oh, the unreasonable big child! If you see your child's misbehaving, why don't you show him the way to reason?"(Comenius, 2017: 91).

As a result, Comenius recognized inductive and deductive methods, whereas "he attached the greatest importance to the syncretic method, which allows the realization of the pansophic assumptions in teaching, that is, it allows to recognize the world as a whole and perceive its harmony" (Suchodolski, 1973: XLV). Comenius formulated sentences or sentence systems which he carefully analysed and compared. As a result, he created detailed tasks from which universal assertions arose and hypotheses emerged. Wishing to strengthen his concept, he checked individual and universal sentences step by step through observations. The carried out observation was related to the assessment of the truth or falsehood of, first and foremost, the unit sentences, and ultimately, of the universal sentences. Comenius ran a "scientific game" which aroused enthusiasm in him; he enjoyed it for itself, every step of the game led to the goal (Lakatos, 1995: 237-242, 261-269). 
Comenius's concept of a man in general, including a free man, is still being interpreted by contemporary representatives of various scientific disciplines, taking into account the Great Pedagogue's seventeenth-century possibilities and scientific conditions (about which I wrote earlier). Over the centuries, since the times of John Amos Comenius, many researchers and interpreters of his life and work have appeared. In the twenty-first century one also observes great interest in this character, because there are still unexplored and not fully interpreted fields on the scale of Poland, Europe and the whole world. Today, comeniology occupies us not only as a field of activity and a social movement, but also - and perhaps above all - as a science. At the beginning I stated a question: is comeniology a science? The answer to this question seems - basing on my considerations and interpretations - not entirely univocal. Comeniology as a science is still in the phase of European discussions based on the continuous researches on John Amos Comenius, their analysis and interpretation.

\section{Bibliography}

Amsterdamski Stefan, Nauka a porzq̨dek świata, Warszawa 1983.

Borkowski Andrzej, Symbole i symbolika w dziełach Jana Amosa Komeńskiego, In: B. Sitarska (ed.), Jan Amos Komeński - Jego pedagogika i filozofia, „Siedleckie Zeszyty Komeniologiczne, seria pedagogika”, vol. II, Siedlce 2015, p. 137-144.

Cackowski Zdzisław, Kmita Jerzy, Szaniawski Klemens, Smoczyński Paweł J., Filozofia a nauka. Zarys encyklopedyczny, Wrocław - Warszawa - Kraków - Gdańsk - Łódź 1987.

Dziewiecki Marek, Osoba i wychowanie. Pedagogika personalistyczna w praktyce, Kraków 2003.

Dziewiecki Marek, Kochać wymagać. Pedagogika Ewangelii, Kraków 2006.

Dziewiecki Marek, Młodzi pytajq̨ o miłość, rodzinę i wychowanie, Kraków 2008.

Furmanek Waldemar, Człowiek - człowieczeństwo - wychowanie (wybrane problemy pedagogiki personalistycznej), Rzeszów 1995.

Heller Michał, Filozofia nauki - wprowadzenie, Kraków 2009.

Jagiełło Ewa, Program Jana Amosa Komeńskiego rozumnego wychowania dzieci $w$ wieku przedszkolnym a wspótpraca przedszkola z rodzicami dzieci $w$ recepcji współczesnych nauczycieli przedszkola, „Siedleckie Zeszyty Komeniologiczne, seria pedagogika", vol. V, Jan Amos Komeński w epoce współczesności. Odczytania - kontynuacje - krytyka, Siedlce 2018, p. 121-168.

Kalita Cezary, Idea wolności w myśli filozoficznej i politycznej siedemnastego wieku, Siedlce 2007. 
Kalita Cezary, Jana Amosa Komeńskiego człowiek jako „wolny użytkownik świata", In: B. Sitarska (ed.), Jan Amos Komeński - współczesne interpretacje i reinterpretacje jego twórczości „Siedleckie Zeszyty Komeniologiczne, seria pedagogika", vol. III, Siedlce 2016, p. 63-70.

Komeński Jan Amos, Pisma wybrane, transl. K. Remerowa, Wrocław - Warszawa - Kraków 1964.

Komeński Jan Amos, Pampaedia, transl. K. Remerowa, Wrocław 1973.

Komeński Jan Amos, Droga światłości, In: B. Suchodolski (ed.), Komeński, Warszawa 1979.

Komeński Jan Amos, Unum necessarium czyli Jedyne konieczne, transl. J. Sachse, Wrocław 1996.

Komeński Jan Amos, Szkoła macierzyńska czyli program rozumnego wychowania dzieci w pierwszych sześciu latach, transl. K. Banszel, Leszno 2017.

Krąpiec Mieczysław Albert, Dzieła. Ja - człowiek, vol IX, Lublin 1991.

Lakatos Imre, Pisma z filozoficznych nauk empirycznych, Warszawa 1995.

Okoń Wincenty, Nowy słownik pedagogiczny, Warszawa 1996.

Olbrycht Katarzyna, Prawda, dobro i piękno w wychowaniu człowieka jako osoby, Katowice 2002.

Popper Karl R., Wiedza obiektywna. Ewolucyjna teoria epistemologiczna, transl. A. Chmielewski, Warszawa 1992.

Sitarska Barbara, Wolność, odpowiedzialność i tożsamość w pogladach Jana Amosa Komeńskiego, In: B. Sitarska (ed.), O Janie Amosie Komeńskim i jego poglądach na edukacje, „Siedleckie Zeszyty Komeniologiczne, seria pedagogika", vol. I, Siedlce 2014, p. 313-324.

Sitarska Barbara, Droga człowieka do poznawania siebie w ujęciu Jana Amosa Komeńskiego, In: B. Sitarska (ed.), Jan Amos Komeński - jego pedagogika i filozofia, "Siedleckie Zeszyty Komeniologiczne, seria pedagogika”, vol. II, Siedlce 2015, p. 145-156.

Suchodolski Bogdan., Wstęp do Komeński J.A., Pampaedia, transl. K. Remerowa, Wrocław 1973.

Sztobryn Sławomir, Jan Amos Komeński (1592-1670) jako przedstawiciel nowożytnej filozofii wychowania, In: B. Sitarska (ed.), Jan Amos Komeński jego pedagogika i filozofia, „Siedleckie Zeszyty Komeniologiczne, seria pedagogika", vol. II, Siedlce 2015, p. 91-100.

Szymonik Danuta, Godność człowieka w ujęciu Jana Amosa Komeńskiego, In: B. Sitarska (ed.), Jan Amos Komeński - jego pedagogika i filozofia, „Siedleckie Zeszyty Komeniologiczne, seria pedagogika", vol. II, Siedlce 2015, p. 129-136.

Węgrzewski Adam, Struktura człowieka w ujęciu Maxa Schelera, „Studia Filozoficzne" 1971, no. 6.

Wielgos Stanisław, Człowiek a centrum wszechświata, „Ethos: kwartalnik Instytutu Jana Pawła II KUL" no. 3, 1999. 